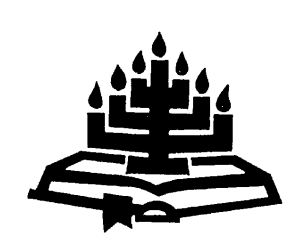

\title{
Van Calvinisme tot eksistensialisme": 'n teologiese gesprek met André P. Brink met verwysing na sy memoirs ${ }^{2}$
}

\author{
J.H. van Wyk \\ Eenheid vir Reformatoriese Teologie \\ Potchefstroomkampus \\ Noordwes-Universiteit \\ POTCHEFSTROOM \\ E-pos: amievw@intekom.co.za
}

\begin{abstract}
From Calvinism to existentialism: a theological discussion with André P. Brink with reference to his memoirs

In this article the author attempts to develop a theological discussion with the well-known and world-famous writer André $P$. Brink, on the topics of Calvinism and existentialism. The question at stake is why Brink, who grew up in a South African Calvinist milieu, which was reinforced by his studies at the Potchefstroom University for Christian Higher Education, turned his back on Calvinism and wholeheartedly embraced existentialism during his study in Paris. Why was Potchefstroom exchanged for Paris? Why was Christ replaced by Camus? Did Brink thoroughly compare Calvinism with existentialism or was his decision taken precipitately? This is the fascinating question which the author tries to unravel in this investigation.
\end{abstract}

$1 \quad$ Met hierdie artikel wil ek graag my waardering teenoor Tjaart van der Walt uitspreek vir sy besondere bydraes tot die teologie, die kerk, die samelewing en die koms van die koninkryk van God in Suid-Afrika.

Persoonlik hou ek nie van die begrip "Calvinisme" nie en sou ek dit graag eerder wou vermy of dit in aanhalingstekens wou gebruik. Hiermee word gewoonlik verwys na die gereformeerde benadering van die Christelike geloof. Ter wille van die argument maak ek egter (teësinnig) van die begrip Calvinisme gebruik.

2 Verwysings wat slegs 'n bladsynommer bevat, verwys na Brink (2009b). 


\section{Opsomming}

\section{Van Calvinisme tot eksistensialisme: 'n teologiese gesprek met André P. Brink met verwysing na sy memoirs}

Die outeur probeer in hierdie artikel om 'n teologiese gesprek met die welbekende en wêreldberoemde skrywer André $P$. Brink te ontwikkel oor die temas van Calvinisme en eksistensialisme. Die groot vraag is waarom Brink, wat in 'n Suid-Afrikaanse Calvinistiese milieu opgegroei het, wat versterk is deur sy studies aan die Potchefstroomse Universiteit vir Christelike Hoër Onderwys, sy rug op die Calvinisme gekeer en die eksistensialisme aanvaar het tydens sy studie in Parys. Waarom is Potchefstroom ingeruil vir Parys? Waarom is Christus vervang met Camus? Het Brink 'n deeglike vergelyking gemaak tussen Calvinisme en eksistensialisme of was sy besluit oorhaastig? Hierdie is die boeiende vraag wat die skrywer in hierdie ondersoek probeer ontrafel.

\section{Inleiding}

Vanselfsprekend sou 'n mens die vraag kon stel of dit verantwoordelik en billik is dat ' $n$ teoloog met 'n romansier in gesprek mag tree, nié oor die letterkunde nie, want daarvoor is 'n teoloog te onkundig, maar oor die teologiese subteks wat - dikwels onbewustelik - in 'n letterkundige werk na die oppervlak kom. Ek meen om op hierdie vraag bevestigend te antwoord. Soos wat letterkundiges die volste reg het om met teoloë in debat te tree, en dit soms ook inderdaad doen, so het teoloë ook die reg om met letterkundiges gedagtes te wissel. Teologie en letterkunde (skryfkuns) kan mekaar ook oor en weer bevrug en verryk. Teologie kan sonder "verwoording" nie bestaan nie en letterkunde nie sonder "begronding" nie. Daarby is ' $n$ roman ' $n$ veeldimensionele aangeleentheid: dit bevat (allereers) 'n estetiese dimensie maar ook 'n politieke dimensie (soos Brink inderdaad erken ${ }^{3}$ ) en waaroor ek reeds met hom in debat getree het (Van Wyk, 1991:62-76), ${ }^{4}$ maar elke roman bevat ook, bewustelik of onbewustelik, direk of indirek, 'n "teologiese", godsdienstige en lewensbeskoulike dimensie - wat ek dan graag in hierdie artikel wil bespreek.

3 Vergelyk wat Brink self sê:

Ek dink nie ek het ooit in my fiksie 'oor' politiek geskryf nie. Politiek het alles deurdrenk wat ek geskryf het. ... Ek glo vas dat geen behoorlike storie ooit vertel kan word sónder 'n politieke dimensie nie. (p. 226.)

$4 \quad$ Dit het gehandel oor die politieke dimensie in die romankuns van Brink. 
Daarby handel hierdie artikel nie oor fiksie nie - hoedanig feit en fiksie ook al, volgens Brink se eie uitlatings in sy romans, vervleg is 5 maar oor 'n outobiografie wat veronderstel is om by die fiktiewe verby te beweeg en op die feitlike te fokus. ${ }^{6}$

Ek het spesifiek besluit om oor Brink te skryf, nie alleen vanweë sy nasionale en internasionale status nie, maar ook omdat hierdie artikel opgedra word aan Tjaart van der Walt en hy en Brink vir 'n geruime tyd saam studente was aan die (destydse) PU vir CHO - Brink van 1953-1959 en Van der Walt van 1951-1958 (Scott, 1998:73-82). Dit is opvallend dat Brink nêrens in sy outobiografie na Van der Walt verwys wat in Brink se tyd twee keer voorsitter van die Studenteraad was nie (1956 en 1957) - asook later rektor van die PUK (19771988). Brink self het, na my beste wete, nooit op die Studenteraad gedien nie (Van der Schyff, 2003:213). ${ }^{7}$ My studentejare aan die PUK dateer van die jare 1955-1961 met die gevolg dat ek albei van hulle van naby leer ken het.

Brink se lewe het 'n bepaalde kronkelgang gegaan, met talle vurke in die pad, soos die titel van sy outobiografie ook aandui. Hy het klaarblyklik in 'n Calvinistiese huis grootgeword en het vir sewe jaar aan 'n Calvinistiese universiteit studeer, en tog het hy met verloop van tyd die Calvinisme afgelê, selfs 'n enorme afkeer daarteen opgebou en uiteindelik gekies vir die lewensbeskouing van die eksistensialisme. Die groot vraag is: waarom? Waarom het Brink die Calvinisme (daardie variant van die Christelike geloof) verruil vir die eksistensialisme? Het die eksistensialisme beter, sinvoller, verantwoordeliker en betekenisvoller antwoorde op die diepste lewensvrae as die Christelike geloof gebied? Soos: waar kom alles vandaan, waar gaan alles heen, wat maak die lewe sinvol en hoe leef ek 'n goeie lewe? Waarom is die antwoorde van Potchefstroom ingeruil

$5 \quad$ Volgens Brink (p. 244) is die roman Orgie (1965) gebaseer op sy verhouding met Ingrid Jonker terwyl 'n Droë wit seisoen (1979) alles op feitlikhede van die jare 70 van die vorige eeu rus (p. 274). Werklikheid en fiksie is haas onskeibaar (p. 106).

6 Van hierdie boek sê Brink: "As jy nie bereid is om in so iets ['n outobiografie] hééltemal eerlik te wees nie, moet jy dit liewer nie aanpak nie." (Stander, 2009:29.) Olivier (2009:11) merk egter op dat hierdie "geen ware outobiografie is nie".

7 Dis opvallend dat Schutte (2005) in sy omvattende studies (volgens die indeks) nêrens na Brink, een van die bekendste oud-Pukke van alle tye, verwys nie. 
vir dié van Parys, Calvyn vir Camus, ja, Christus vir Camus? Waarin oortref die eksistensialisme van Camus die evangelie van Christus?

Dit is hiérdie boeiende vrae wat ek graag in hierdie artikel wil ondersoek en waarop ek 'n antwoord gaan probeer soek, met die uitdruklike beperking dat ek vir hierdie doel slegs gaan fokus op Brink se outobiografie en nie op sy totale oeuvre nie. ${ }^{8}$

Voordat ek hiertoe oorgaan, wil ek by wyse van 'n ekskurs daarop wys dat die Calvinisme as lewens- en wêreldbeskouing al hoe meer deur hedendaagse skrywers gekritiseer en onder druk geplaas word - en 'n mens wonder waarom. Is dit omdat Calviniste (Christene) so oncalvinisties (onchristelik) lewe (en geleef het), of omdat die Calvinisme in sy Suid-Afrikaanse gedaante die dwaling van apartheid so kritiekloos aanvaar en selfs teologies ondersteun het? Maar dan kan dit tog nie van alle Calviniste gesê word nie? Brink (p. 407, 455) verwys self na Beyers Naudé, daardie "stoere Calvinis", as ligtende voorbeeld in hierdie verband. En hy kon nog na vele ander verwys het, soos byvoorbeeld Willie Jonker - mense wat juis op grond van hulle Calvinistiese benadering apartheid as 'n onmenslike, onbybelse en onchristelike ideologie verwerp het.

In elk geval is dit duidelik dat talle skrywers 'n groot renons in die Calvinisme ontwikkel het.

\section{Die Calvinisme in die spervuur}

Die Calvinisme staan vandag in die spervuur. Tydens die 500e herdenkingsjaar van Calvyn se geboorte in 2009, was die dagblaaie met hoofsaaklik kritiese artikels gevul. Die Calvinisme word deur vele verwerp veral vanweë sy siening van sonde, skuld en seksualiteit. By talle skrywers vind ons dieselfde soort kritiek en ek verwys slegs na enkele voorbeelde.

Die Calvinisme, sê Marita van der Vyver (2008:11), sorg waarskynlik steeds dat arme jonge Suid-Afrikaanse meisies oor alles skuldig

8 Persoonlik beskou ek, saam met Daniël Hugo (2005:47), Bidsprinkaan (2005) as een van Brink se beste romans. Hang dit daarmee saam dat Brink hom hierin verdiep in 'n vir hom bekende tema, naamlik godsdiens, en dui dit daarop dat hy hom van hierdie tema nie kán losmaak nie? Vergelyk byvoorbeeld die selfgesprek van eerwaarde James Read: "Kan die hart ooit sy eie donker redenasies deurgrond? Waar eindig die genade en die onbegryplike wil van God, waar begin die mens se wederstrewigheid?" (Brink, 2005:106). Waar kom Brink aan hierdie woorde? Kom dit uit 'n argief - of uit sy eie hart? 
voel. "Ouers maak nog steeds hul kinders groot om skuldig te voel." En verder: "Ek het soveel jare lank teen Calvinisme gestry dat ek dit nou al onbewustelik doen."

Kleinboer (2003:27), in sy eroties gelade roman, Kontrei, ${ }^{9}$ stem hiermee saam: "Ek moes oor 'n groot oseaan na 'n ander kontinent vlieg, wegkom uit die lang Calvinistiese skadu van opvoeding wat aanhou inhamer het mens moét getroud wees voor jy [seksuele] gemeenskap kan hê."

Volgens Martin Labuschagne (2007:3) het die Christelike siening van erfsonde, wat sy uiterste in die Calvinisme bereik het, daartoe gelei dat miljoene mense 'n permanent beskadigde selfbeeld ontwikkel het. "Dit is weens dié kultuur van skuldgevoel dat Afrikaners op politieke gebied gekapituleer het."

Die joernalis Chris Louw (2001:12) vertel hoedat hy "voor die einde van sy skoolloopbaan" die Calvinisme afgesweer het. Hy het egter eers in 1974 as lidmaat van 'n Gereformeerde gemeente bedank, want hy was teen daardie tyd "hartlik gatvol vir die huigelary en die skynheiligheid van die Afrikaanse kerke - toe nog nie oor hul rassisme nie, maar oor hul onverdraagsaamheid" (Louw, 2001:137).

Louw verset hom veral teen die Calvinisme van Potchefstroom, veral soos dit gestalte gevind het in die boek Roeping en werklikheid (De Klerk et al. 1972). ${ }^{10}$ Louw (2001:161) beskou die invloed van hierdie boek as "onverbloemde propaganda vir die Nasionale Partyideologie".11

$9 \quad$ Ek het die boek met groot moeite deurgelees en was dit nie vir die talle Bybelverwysings nie, sou ek nie verder as kwartpad gevorder het nie.

10 Die skrywer, J(an) $H$ (endrik) van Wyk van hierdie boek was 'n opvoedkundige aan die PU vir $\mathrm{CHO}$ en moet onderskei word van die skrywer van hierdie artikel met die volle name Jan Harm.

11 In sy bespreking van hierdie boek gaan Louw (2001:228-231) egter uiters selektief te werk en laat hy na om te meld dat De Klerk et al. (1972:327) ook klem gelê het op sake soos politieke geregtigheid en selfs gelykheid, "wat inhou dat een volk oor 'n ander nie mag heers nie", asook dat naas die bevordering van blanke eenheid, ook "die uitbouing van die breëre nasionalisme" belangrik is (De Klerk et al., 1972:329). Hy laat ook na om deeglik aandag te gee aan die kritiese gesprek wat die PU vir CHO oor apartheid gestimuleer het. Die vraag is tereg al byvoorbeeld deur Anesu de Vos aan Louw gestel waarom hy self so lank deel van "die sisteem" gebly het voordat hy apartheid begin kritiseer het hy het eers in 1986 by Perskor bedank (Louw, 2001:134,140) en later in Londen "die lig gesien" (Louw, 2001:141, 145-146, 176). 
Só gesien het Suid-Afrika 'n gevaarlike land geword: eers was daar die Roomse gevaar, toe die Swart gevaar, later die Rooi en Pienk gevare en tans is daar die Calvinistiese gevaar.

Ons keer terug na die begin van ons verhaal en gee aandag aan Brink as Calvinis.

\section{Brink as Calvinis: "met geesdrif op die Calvinistiese koers"12}

In sy outobiografie verwys Brink herhaaldelik na sy Calvinistiese agtergrond, meesal in negatiewe sin. So verwys hy byvoorbeeld na "daardie dorre Calvinistiese [ere]dienste" (p. 70) waarop hy later sy rug gedraai het en reeds op veertien geweier het om 'n erediens by te woon (p. 71). Soos bovermelde skrywers kan ook hy nie help om "te dink dat die gruwelike skuldgevoelens wat daar dwarsdeur my hele jeug aan seks gekleef het maar net die vernietigende gevolg van die Calvinisme was nie ..." (p. 49). Gewoonlik is dans en seks saamgedink: "Ons stigtelike Potchefstroomse Universiteit, moet ek tot my skande sê, het dans gebrandmerk as so ongeveer die ergste doodsonde in die Christendom" (p. 151) - hoewel Brink opmerk dat hy self nie meer as vyf of ses keer in sy lewe gedans het nie (p. 407).

Aan Sonja Loots (2004:iv) sê hy: "Sien, ek het verskriklik beskimmeld grootgeword en boonop met die helse las van die Calvinisme" (met verwysing na die seksuele).

Dat die jong Brink hom egter as student volledig tuisgevoel het in die Calvinistiese tradisie, blyk uit 'n jeugartikel wat hy op 22-jarige ouderdom op die PUK oor Christelik-Nasionale Onderwys geskryf het.13 "Christelik" beteken dan in hierdie geval "opvoeding soos bepaal deur die belydenisskrifte van die drie Afrikaanse Kerke" (Brink, 1957:116). Die Christelik-nasionale gees moet elke faset van die skoollewe deurstraal: metodiek, kind, onderwyser, dissipline, organisasie en beheer. Niks is hier uitgesluit nie (Brink, 1957:117).

12 Die Calvinisme word gewoonlik in terme van die bekende vyf solismes van die Reformasie van die sestiende eeu gedefinieer: aan God alleen die eer ( $\mathrm{Hy}$ regeer soewerein); Christus alleen (slegs Hy is Verlosser en Koning); redding uit genade alleen; redding deur geloof alleen; en die Woord alleen (as hoofbron van lig en lewe).

13 Brink se bronnelys verwys veral na die werke van die PUK-opvoedkundige (en latere rektor) J. Chr. Coetzee. 
Die Christenouer het 'n Godgegewe, selfs Godopgelegde, reg om te eis dat sy kind op Christelike grondslag opgevoed word, nes die nasionale ouer kan eis dat sy kind die kultuur- en volksbesit van sy eie volk in sy opvoeding sal ontvang. (Brink, 1957:118.)

Die skool moet ook 'n juiste kindbeskouing handhaaf. Die kind is immers beeld van God, en iemand wat, hoewel belas met die oersonde, deel het aan die genadeverbond van God. "Die opvoeding het dus ten doel om daardie kind as mens voor te berei en te ontwikkel tot eer van God, tot kennis van Sy wet en tot uiteindelike volmaaktheid in die hiernamaals." (Brink, 1957:118.)

Die Christelik-nasionale lewens- en wêreldbeskouing eis dat moedertaalonderrig geskied, dat godsdiensonderrig volgens die belydenisskrifte van die Afrikaanse Kerke verskaf word en dat alle vakke op skool in die lig van die Christelik-nasionale beginsel gedoseer sal word. ... Dit is immers onmoontlik om ooit waaragtig neutraal te wees. (Brink, 1957:118.)

Die kernstandpunt is die onmoontlikheid en die onduldbaarheid van neutraliteit in enige mens. Die Christen is deur God geroep om uit te gaan en die evangelie te versprei. Maar die Christelike lewens- en wêreldbeskouing word vir ons bepaal deur die eiesoortigheid van die volk waarin dit wortel, omdat die besondere vertolking van die Christelike leer suiwer aanpas by die volk waarin dit gegroei het. (Brink, 1957:119.)

Oor hierdie benadering van hom tydens sy jare op die PUK sou Brink 52 jaar later opmerk: "Op die oppervlak het ek op die Calvinistiese koers gebly, dikwels selfs met geesdrif, terwyl ek daarónder ewe toegewyd, en met 'n gevoel van 'n "roeping" my bes gedoen het om dit te saboteer" (p. 143). ${ }^{14}$ Tydens sy studentedae het hy dit geniet om teen die grein van die plek (PUK) in te leef (p. 215). Dit is hieruit duidelik dat hy in hierdie tyd 'n soort dubbele lewe gevoer het.

Hierdie dubbelheid tree reeds in sy vroeë jeug aan die lig wanneer hy vertel van 'n garagediens wat hy as jong seun vir huisbediendes gehou het (p. 63-64) - met "bloedstollende prediking, luidrugtige sang en hartstogtelike gebed". Tydens een van hierdie dienste het hy aan sy swart gehoor verduidelik dat swart mense uit die geslag van Gam afstam en dat "hulle die bediendes vir ons wittes moet

14 Andersyds verwys Brink daarna dat ons studente op die PUK almal "oortuigde jong Calviniste" was (p. 141). Op Potchefstroom was hy "baie godsdienstig" (p. 153). Hy was ook lid van die Jeugbond en die KJV. 
wees". Voordat die diens begin het, het hy besluit om 'n wonderwerk te laat gebeur. Dit het soos volg gebeur: voor die diens het hy ongesiens 'n piering met brandspiritus in sy "preekstoel" (wat uit twee kratte bestaan het) geplaas. Met sy toetrede na die "preekstoel" het hy 'n tweede piering ingebring, dié keer gevul met water. Ná die diens het hy die piering met water rondgestuur en almal kon proe dat dit water is. Daarna het hy "die Here aangeroep om oor ons neer te daal", waarna hy die eerste piering uitgehaal en met 'n vuurhoutjie aan die brand gesteek het. En siedaar, die wonderwerk het plaasgevind! - en die getalle het gegroei. Brink voeg by: dis een van sy "skuldigste herinneringe". Maar voorwaar, 'n vreemde soort handeling vir ' $n$ jong Calvinis.

Die prentjie wat Brink van die Calvinistiese PUK skilder, is nie altyd mooi nie, alhoewel hy toegee dat die historikus prof. D.W. Kruger, met 'n lesing oor die Franse Rewolusie, die eerste saadjie vir vernuwende denke by hom gesaai het (p. 56). Ongetwyfeld is daar waardering vir destydse dosente soos D.W. Kruger (p. 56), L.J. du Plessis (p. 58, 242), H.J.J. Bingle (p. 143), G. Dekker (p. 239) en T.T. Cloete (p. 258), maar dikwels kom hulle in 'n kritiese verband ter sprake.15 lemand vir wie Brink egter nie ooghare het nie, is sy studentemaat F.W. de Klerk. Van De Klerk word gesê dat sy "mees opvallende eienskap was 'n drang om mense ter wille te wees en 'n bereidwilligheid, selfs gretigheid, om nogal laag te kruip om dit te bereik" (p. 144). De Klerk het altyd die regte kanale gevolg om in die studentehiërargie te vorder - terwyl Brink hom aan die kant van die ketters geskaar het (p. 443).16 Later sou hy De Klerk skerp kritiseer

15 Interessant genoeg verwys Brink nêrens na die bekende filosoof H.G. Stoker nie. Stoker was vir lang periodes nóú by die aanbied van Geloofsleer betrokke (vgl p. 414); sy (nogal droë) boek Beginsels en metodes in die wetenskap (1961) het later die standaard voorgeskrewe boek geword. Stoker het bekend geword vir sy "Wysbegeerte van die skeppingsidee", vgl. sy Oorsprong en rigting 1 en 2 (Stoker, 1967; 1970). Die (verpligte "Geloofsleer"-kursus het 'n lang ontwikkelingsgeskiedenis gehad: Dit is eers "Kulturele Roepingsleer" genoem, daarna "Beginsel- en Metodeleer", toe "Studium Universale", hierna "Etiek en Logika", toe "Interfakultêre Wysbegeerte", daarna "Wetenskapsleer" en uiteindelik "Reformatoriese Wetenskap" (vgl Van Eeden, 2005:503) en dit was vir alle studente verpligtend.

16 Ek moet eerlik sê dat my ervaring van De Klerk, met wie ek in 1958 in die Studenteraad gedien het, anders was. Veel later, in 1991, het ek uit waardering een van my boeke aan FW en Marike opgedra. Vergelyk in hierdie verband die mening van Alan Maker (2001:196-197) 'n Presbiteriaanse predikant van Johannesburg, dat die NG Kerk, vanweë sy diep betrokkenheid by apartheid nie 'n persoon soos F.W. de Klerk kón opgelewer het nie, maar die Doppers wél. Persoonlik meen ek dat een van die grootste politieke foute wat De Klerk 
omdat hy 'n hand gehad het in die drakoniese Sensuurwet van 1974 (p. 251). De Klerk het ook van die boosste apartheidswette deur die parlement geloods (p. 441). Nog later verwys hy na vroeë gesprekke van Mandela vanuit sy tronksel met 'n "teësinnige en wankelmoedige" De Klerk (p. 402). 17 Nêrens is daar enige vermelding van, of waardering, vir die groot stap wat De Klerk in 1990 gemaak het om die verbode organisasies te ontban en Mandela vry te laat nie. Al wat vermeld word, is dat De Klerk vaardig en geslepe genoeg was om "met styl" te abdikeer (p. 441). Dat die (Calvinistiese) beginsel van geregtigheid by De Klerk 'n deurslaggewende rol in sy oorgangsdenke gespeel het, soos De Klerk herhaaldelik in sy outobiografie aanvoer (De Klerk, 1998:59, 110, 167, 169, 178), en wat deur sy vrou, Marike, beaam is (Maartens, 1998:172), kom by Brink nêrens ter sprake nie. 18

Teen die einde van sy boek verwys Brink na optredes van die PUK se eerste rugbyspan, destyds ironies "Theos" genoem, wat nadere aandag verdien (p. 472-473). Hy noem veral twee sake. Die span het altyd Saterdagaande na 'n wedstryd op 'n buurdorp na Potchefstroom teruggekeer, "omdat dit vir hulle as vroom Calviniste sonde was om op Sondag te reis" en daardeur die Sabbat te ontheilig. Hierdie opmerking is egter vergesog. Al die omliggende dorpe rondom Potchefstroom was maklik bereikbaar en dit sou tog onsinnig wees om ekstra hotelkoste vir vyftien spelers vir Saterdagnag aan te gaan ten einde eers Sondagoggende terug te keer. Terugkeer op Saterdagaande was 'n logiese stap, om nog daardie aand te kon "sleep", asook om Sondagoggend 'n erediens te kon bywoon.

Die tweede opmerking gaan daaroor dat hierdie rugbyspan, wanneer hulle Saterdagaande na Potchefstroom teruggekeer het, "elke keer wanneer hulle 'n swart man, of 'n groepie swart mans langs die pad teëkom", hulle "uitmekaar sou slaan"(p. 472-473). Ek het hierdie stelling sover moontlik by 'n aantal spelers probeer verifieer - ek het

gemaak het, was dat hy die NP in 1996 onttrek het aan die tussentydse regering van nasionale eenheid. Daarmee het hy die institusionele geheue van die regering vernietig en die geleidelike oordrag van kundigheid en ervaring beëindig. Brink was ook vir 'n kort tydjie saam met De Klerk in die Ruiterwag (p. 143).

17 De Klerk het nooit met Mandela gepraat terwyl Mandela nog in die tronk was nie; daar was wel een gesprek, maar dit was buite die tronk, net voor Mandela vrygelaat is.

18 Selfs Van Zyl Slabbert (2006:35) ondervind moeite om presies uit maak wáárom F. W. de Klerk die sprong gewaag het. 
self in die jare 1957-1960 vir die eerste span gespeel - sonder om iemand te vind wat sulke (laakbare) optredes kan onthou. Daarmee is natuurlik nié gesê dat dit nooit gebeur het nie, wél dat dit ongetwyfeld nie "elke keer" die geval was nie, in elk geval nooit gedurende my termyn nie. 19

\section{Brink as eksistensialis20: "daar's ander moontlikhede ook"21}

Uiteindelik het Brink die Calvinisme die rug toegekeer en die eksistensialisme gekies. Hoe het dit gekom en waarom het hy dit gedoen?

Wat het gebeur dat hy twee jaar na sy terugkeer uit Parys (in 1963?) aan F.W. de Klerk skryf "hoe die gebeure in Frankryk my daartoe gebring het om álles wat ek vantevore as vanselfsprekend aanvaar het te verwerp" (p. 144)?

In 'n gesprek met Hanlie Retief noem hy dat hy nie saam met die "Dopperbrigade"22 na Amsterdam toe is vir nagraadse studie nie,

19 Daar is ook ander opsigtelike kleinere feitefoute in die boek soos byvoorbeeld: Jona was nie in 'n "walvis" nie (p. 62); Chum Ochse en Tom van Vollenhoven het nooit saam in dieselfde agterlyn gespeel nie (p. 75); Basil Kenyon was nie 'n "slot" nie (maar 'n agsteman) (p. 76); en Markus was nie 'n "apostel"nie (p. 213).

20 Stumpf (1988:512) definieer eksistensialisme soos volg:
A mode of philosophy which focuses upon the existing individual per- son; instead of searching for truth in distant universal concepts, exis- tentialism is concerned with authentic concerns of concrete existing individuals as they face choices of decisions in daily life.

Met ander woorde "eksistensie" gaan aan "essensie" vooraf.

21 Burger (2010:3) verwys na die Brink-kenner G. Meintjes wat van oordeel is dat Brink se oeuvre in drie fases verdeel kan word: die eksperimenteel eksistensialistiese fase van die sestigerjare, die "(politiek-)betrokke" fase van die sewentiger- en tagtigerjare en die postmodernistiese/postkoloniale fase sedert die negentigerjare. Brink (2009a) bly egter tot die einde deur die eksistensialisme geboei.

22 Hierdie sou moontlik as 'n sinspeling op Tjaart van der Walt gesien kon word, hoewel Tjaart in 1959 na Kampen is en daar 'n uitstekende proefskrif oor Die koninkryk van God - naby! in 1962 voltooi het. Heelwat PUK-filosowe het hulle egter wel na Amsterdam gewend. (Ek is self in 1969 daarheen.) Van der Walt se proefskrif verskyn dieselfde jaar (1962) toe twee ander proefskrifte, dié van Kuitert (1962) oor die Godsleer en dié van Rothuizen (1962) oor die Wet verskyn het en die Nederlandse teologiese debat oorheers het. Gevolglik het die proefskrif van Van der Walt daardie jaar minder aandag ontvang as wat dit verdien het. Vergelyk egter die breedvoerige bespreking daarvan deur sy 
maar (in 1959) na Parys. "So rou en Calvinisties ingeperk. Parys het my laat ontdek daar's ander moontlikhede ook" (Retief, 2005:3).

Sy kennismaking met die eksistensialisme het sy sekerhede ondermyn: "ek het nie meer geweet wie ek is nie" en so is hy gedryf tot 'n eksistensiële ondervraging van homself (p. 53).

Dit is duidelik dat die eksistensialisme Brink na sy eerste besoek aan Parys (1959-1961) hoe langer hoe meer geboei en uiteindelik oorrompel het. Hy het algaande 'n bewondering vir Sartre 23 en veral ook vir Camus ontwikkel (p. 148). "Meer as enigiets of enigiemand anders was dit hý wat my as student Parys toe gedwing het", ja, sy "hele destydse verblyf in Parys het in die teken van Camus gestaan" (Brink, 2009b:14). Hy het versot geraak op Camus (p. 92), en Camus het sy Bybel geword, sy vademecum (naslaanboek vir alles) (p. 154), "die bloudruk vir die res van my lewe" (p. 149). By Camus het sy onrustige hart tot rus gekom (om 'n Augustiniaanse uitdrukking te varieer - Augustinus het volgens Brink (2009b:14) blykbaar "'n grondslag vir Camus se werk gelê". (Algerië is die bakermat van albei.) By die eksistensialisme van Camus het hy gevind wat hy by die Calvinisme so gemis het, naamlik die waardes van vryheid, waarheid en geregtigheid (p. 469), die eindelose opstand teen onreg, leuens en onvryheid (p. 149). Teen die absurditeite van die lewe is daar net een moontlikheid, net een verantwoordelikheid, en dit is verset en rebellie: "Ek rebelleer, daarom is ons", sou Camus sê (p. 311). Toe Brink per geleentheid die studente van Rhodes in Grahamstad toespreek, is sy boodskap, in aansluiting by Camus, eenvoudig: dit is noodsaaklik om nooit op te hou om te protesteer nie (p. 277). Brink is sodanig deur die figuur van Camus geboei, dat hy 'n persoonlike "pelgrimstog" na sy land van geboorte, Algerië, onderneem het (Brink, 2009b:14-15). Blykbaar het Brink egter geen behoefte daaraan gehad om ook die woon- en werkplekke van een van die grootste teoloë van alle tye, Augustinus, te besoek nie.

Die studente-opstand van 1968 in Parys het sy lewensvisie totaal verander. Hy het ontdek dat daar 'n dieper onrus ágter die opstande

vroeëre leermeester W.J. Snyman (1977:176-195). Omdat Van der Walt vir 'n lang periode die aktiewe akademie verlaat het, was sy teologiese bydrae minder omvattend as wat dit andersins sou gewees het (vgl. Van der Walt, 2006; 2009). gesien het (Brink, 2009a:14). 
skuil: die behoefte aan 'n nuwe soort samelewing met 'n nuwe waardestelsel (p. 319). Op die plakkate was dit te sien: Net die waarheid is revolusionêr, net die revolusie is waar (p. 323). Van toe af het Brink 'n politieke mens geword.

Van nou af sal dit skynheilig wees om my te verbeel dat die politiek iets aparts kan bly, 'n afgebakende gebied los van my totale belewenis. Dit is oral. Dit deurdring alles. Dit kan nooit weer afsonderlik van die geheel bestaan nie. (p. 324.)

'n Nuwe samelewing is nodig wat uit deelname en betrokkenheid bestaan, spontaan en van binne af (p. 334).

Brink se afwysing van die Calvinisme en aansluiting by die eksistensialisme het op twee pylers gerus: enersyds die ontoereikendheid, selfs afstootlikheid van die Calvinisme, en anderyds die aantreklikheid en aanloklikheid van die eksistensialisme (p. 215).

Dit is duidelik dat ' $n$ hele aantal gebeure daartoe aanleiding gegee het dat Brink hom hoe langer hoe verder van die Calvinisme verwyder het.24 Daar is, om te begin, die Godsleer, die gewelddadige en bloeddorstige God wat ons in die Bybel ontdek (p. 19-20, 62, 430). 25 Selfs Jesus is volgens hom in hierdie opsig verdag (p. 20).

Die hele gedagte van ontsag vir (die gesag van) God het intimiderend gewerk.

24 Brink (p. 199-200) betreur dit ook dat die eerste koloniste in Suid-Afrika uit Holland gekom het, met 'n fundamentalistiese vorm van Calvinisme, wat later deur die Franse Hugenote ewe fundamentalisties versterk is. Daarby het amptenare van die VOC kinders by slavinne verwek met "Calvinistiese deeglikheid" (p. 204).

25 Met die naderende dood van sy ma spot Brink met God. Sy is nie op die verwagte tyd oorlede nie. "God moet hom met die boodskap misgis het - hy raak ook al oud -" En toe sy ma sterf, het sy "God met 'n systappie ontwyk voordat hy sy opwagting kon maak" (p. 375). 'n Mens vra jou af of Brink se deurlopende slegte verhouding met sy pa nie sy Godsbeeld nadelig beïnvloed het nie. Hy skryf dat hy "nooit 'n baie hegte verhouding [met sy pa] gehad het nie" (p. 40; vgl p. 73). Hy beskryf sy pa as die bestendige, voorspelbare, betroubare steunpilaar met 'n onbegryplike en onbereikbare binneste (p. 135). Hy was altyd op soek na tekens van toegeneentheid by sy pa, maar wat hy gevind het, was altyd iets afstandeliks (p. 370). Daar was selfs 'n gebeurtenis wat hy sy pa "nooit kon vergewe nie" toe sy pa hom (met sy pa se eie siekte) sielkundig afgedreig het om nié 'n begrafnisrede by Bram Fischer in Bloemfontein te kon hou nie (p. 390). Brink het alles verteenwoordig wat sy pa (en die $A B$ ) verfoeilik en verwerplik gevind het (p. 385). (Soms kry 'n mens die indruk dat Brink sy eie manlikheid oormatig wil aksentueer en demonstreer.) 
Ek weet glad nie meer hoe die verskuiwing gekom het nie, en dit was eers baie later dat ek besef het wat uit die staanspoor al vanselfsprekend moet gewees het: dat dit juis die teenwoordigheid van gesag, die feit van mag is wat rebellie uitdaag en moontlik maak. Sonder die bedreiging van mag kan die ketter die een wat kies - nie bestaan nie. (p. 71.) ${ }^{26}$

Daar is verder ook die ontoereikendheid van die Christelike geloof:

Die rede waarom godsdiens my op die lange duur teleurgestel het (en dit hét nogal lank geduur om die sprong te waag), was eenvoudig die feit dat dit net nie meer my ingebore behoefte aan skouspel en drama kon vervul nie. (p. 60.)

Nog 'n faktor is die skynheiligheid van die (Calvinistiese) kerk en sy ampsdraers. Brink vertel van 'n brief ("daardie brief" - p. 72) wat 'n dominee se vrou aan sy ma geskryf het en waarop Brink terloops afgekom en gelees het. Daarin vertel sy van hoe haar domineeman by die vroue van diakens rondslaap en hoe hy haar skop en slaan (p. 24). En dan preek die dominee Sondae met 'n vroom gesig! "Wat beteken dat as die dominee besmet is, God self onder verdenking staan." (p. 73.) By 'n ander geleentheid weier 'n dominee dat sy seun sy verhouding met sy gekleurde meisie voortsit, want "die Bybel leer ons ... om nie omgang te hê met die diere van die veld nie" (Brink, 2009:395). In 'n ander geval weer het Brink verraai gevoel deur die optrede van 'n "godsman", toe die verbod op sy boek Kennis van die aand, heroorweeg is (p. 258). ${ }^{27}$

Daar is ook nog die feit dat die Afrikaanse Calvinistiese kerke die beleid en ideologie van apartheid kritiekloos aanvaar, ondersteun en

26 Brink (p. 108) verwys daarna dat hy tydens sy verhouding met Ingrid Jonker (1963-1965) besig was om volledig van die kerk weg te breek.

27 Brink verwys hier na die bekende skrywer ds. Izak de Villiers (vgl. ook p. 340). Vergelyk in hierdie verband De Villiers (2009:83) se weergawe van die gebeure. Steyn (2008:251-254) bied 'n kort weergawe van die debat rondom die publikasie van Kennis van die aand. Ek herinner my goed hoedat ek in 1973 kort na die verskyning van Kennis van die aand (Brink se eerste openlike boek teen apartheid - p. 245) 'n week bestee het om die boek (wat ek by iemand geleen het) in een sessie deur te lees. Die boek het in die GKSA opslae gemaak toe 'n teologiese professor D.C.S. van der Merwe ('n ondersoekende denker) in Rapport 'n resensie daaroor geskryf het - vir die Kuratorium egter 'n te milde resensie en hulle het hom daaroor voor stok gekry. In Die Kerkblad van 10 April 1974 verskyn 'n kennisgewing van die kant van die Kuratorium dat Van der Merwe "al sy gewraakte uitsprake [in Rapport van 27 Jan. 1974] heeltemal terugtrek" en gevolglik met sy werk mag voortgaan. 
teologies fundeer het. Brink het met skok ontdek dat "my mense" hulle gebou van Christelike moraliteit en beskawing opgerig het op gruwele en perverse misdade (p. 158). "Nasionale beleid het nog altyd staatgemaak op die ondersteuning van die Afrikaanse Gereformeerde kerke" (p. 238) - al gee Brink graag toe dat die Afrikaner gevoed is deur die vryheidstryd van die ABO (p. 242). Die grootste boosheid van apartheid was egter nie die fisiese gruweldade nie, maar die psigiese geweld, die geweld teen menslike gemoedere (p. 415). Een van die wreedste vorms van lyding wat apartheid veroorsaak het, was die manier waarop dit ontelbare mense van "' $n$ volle emosionele lewe beroof het" (p. 388).

Die Sharpeville-gebeure van 1960 het alles verander en alle pogings om regverdiging te vind, vernietig (p. 156). Daar in die Luxembourgtuin in Parys in 1960 is hy opnuut gebore, net 'n paar maande nadat hy by die Ruiterwag aangesluit het (p. 157).28

Hierby moet natuurlik gevoeg word dat die veiligheidspolisie in SuidAfrika dit vir Brink hoe langer hoe moeiliker gemaak het. "Die establishment het ons [die Sestigers] gesien as die beliggaming van al die vernietigende magte van Satan en die Antichris. Sondag na Sondag is ons aangeval van die preekstoele van die NG Kerk." (p. 238.) Hoewel Brink nie geglo het aan geweld as oplossing vir die SuidAfrikaanse vraagstukke nie (p. 266; hy is nie "revolusionêre materiaal" nie - p. 2009:332), was die Veiligheidspolisie dwarsdeur die dekade van die sewentigerjare op sy spoor (p. 267), en het hy oproepe, doodsdreigemente, 'n brandbom en agtervolgings ervaar (p. 268). Sy reaksie hierop is dat 'n skrywer net één wapen teen die gruwele van die geskiedenis het, naamlik die woord (p. 362); deur die woord word ons eerste bewus van ons menslikheid (p. 473). Ons ís van Afrika, hóórt hier en wíl hier wees (p. 218).

Talle faktore het dus 'n rol gespeel by Brink se afwysing van die Afrikanernasionalisme en die Calvinisme daarmee saam. Van die faktore was onder andere 'n geskiedenislesing deur D.W. Kruger, die optrede van die apartheidsregering en die kerklike ondersteuning

28 Dit val op dat Brink hier glad nie verwys na die Cottesloe-beraad wat kort na Sharpeville (Maart 1960) deur die WRK belê is (Des. 1960) en waar apartheid in geen onsekere terme afgekeur is nie. Hy verwys ook nêrens na die deurlopende verset van die NG-teoloog en oortuigde "Calvinis" W.D. Jonker teen apartheid nie (vgl. Jonker, 1998). In 1990 het Jonker tydens die Rustenburg-beraad 'n opspaakwekkende skuldbelydenis oor apartheid namens die NGK en die Afrikanervolk gedoen (Jonker, 1998:192-218). Jonker was in Brink se tyd leraar van die NG Kerkstudentegemeente in Potchefstroom. 
wat dit geniet het, sy verhouding met $\mathrm{H}$ (p. 214),29 die moedige optrede van Beyers Naudé (p. 243) ${ }^{30}$ en Tutu (p. 455), die Parys-opstande van 1968 en die boeke van eksistensialiste (w.o. Camus) (p. 55).

\section{Kritiese oorwegings}

Ons het die roete wat Brink beweeg het om die Calvinisme vir eksistensialisme te verruil, probeer volg. Wanneer iemand egter 'n nuwe lewensbeskouing vir 'n ander een verruil, behoort myns insiens ten minste vyf sake ernstig oorweeg te word:

Die swak punte van sy bestaande lewensbeskouing moet eerstens diepgaande ontleed word. Ons het gesien dat Brink ernstige kritiek teen die Calvinisme en sy Suid-Afrikaanse gestalte na vore gebring het. Calviniste kan nie ontken dat sommige van hulle kniediep by apartheid en die teologiese regverdiging daarvan betrokke was nie. Hier dink ek aan eminente teoloë soos E.P. Groenewald, J.D. du Toit en H.P. Wolmarans (vgl. Van Wyk, 1993:39-60). Daar kan egter moeilik toegegee word aan die aantyging dat die $\mathrm{PU}$ vir $\mathrm{CHO}$ hom volledig en goedkoop aan die apartheidsideologie oorgegee het. Die Afrikaanse Calvinistiese Beweging (veral tydens die kongres van 1976), en sy mondstuk, Woord en Daad, het dikwels 'n kritiese stem laat hoor en so 'n kritiese debat gestimuleer. Die "stem van Potchefstroom" was dikwels 'n krities-ondersoekende en bevraagtekenende stem. Reeds in 1959 het professore Wikus du Plessis, Hennie Coetzee en Daantjie Kruger die apartheidsbeleid van die regering in die Sunday Times bevraagteken (Van Eeden, 2005:490, 495). In 1973 was die PUK die eerste Afrikaanse universiteit wat swart nagraadse studente toegelaat het, en eweneens ook in 1983 die eerste wat swart voorgraadse studente toegelaat het; 31 ook die eerste Afri-

29 Sy is later geïdentifiseer as Hermione, 'n uitgesproke Marxis (Meiring, 2009:iv), en iemand wat hy in Grahamstad ontmoet het (p. 214). Sy het "die mees deurslaggewende rol gespeel om aan my politieke gewete en begrip vorm en beslag te gee" (p. 214).

30 "Hy was ongetwyfeld een van die mense wat my die sterkste in my lewe beïnvloed het." (p. 243.) Vergelyk Naudé (1995:79, 88, 162-164) se (ouderwetse) standpunt dat die kerk hom wel met politiek mag bemoei, maar nie met partypolitiek nie. Die apartheidsbeleid was immers nie bloot 'n "politieke" beleid nie, maar duidelik ook 'n "partypolitieke" beleid.

31 Hierdie besluit is tydens die rektoraat van Tjaart van der Walt deur die Raad geneem. Dit is deur Scott (1998:80) beskryf as "die mees ingrypende koersverandering van die Raad" vir destyds. 
kaanse universiteit waar wit en swart teologiese opleiding in 1995 verenig is (hoewel hierdie laaste eerstens 'n kerklike besluit was). In 1977 het die kritiese Koinonia-Verklaring verskyn en in 1990 het 'n oud-PUK en Calvinistiese staatspresident 'n nuwe bedeling vir SuidAfrika aangekondig. In 1997 het drie dosente en 'n dominee 'n Openbare Skuldbelydenis oor apartheid die lig laat sien. 32

Ek vermoed dat die grootste enkele saak van die Calvinisme wat Brink die grootste pyn gee, die diepgaande sondebesef is wat hier aangetref word. Wat daarmee saamgaan, is 'n ewe diep skuldgevoel in die geval van oortreding, ook seksuele oortreding. Hierteenoor moet die vraag gestel word hoe 'n samelewing daar sal uitsien wanneer lieg en bedrieg, hoer en rumoer, moord, misdaad en mishandeling, magsmisbruik en manipulasie, korrupsie en omkopery sonder enige skuldgevoelens hoogty vier. Is so 'n samelewing nie op pad na die afgrond nie?33

Daar moet toegegee word dat die Calvinisme, en tewens ook die Katolisisme, op die terrein van seksualiteit - en die twee hooftemas van Brink se boeke is politiek en seksualiteit - ongetwyfeld gegly het. Hierdie donker siening van seksualiteit kom egter van ver af,

32 Kort ná die verskyning van die Skuldbelydenis is daar by die Kuratorium van die GKSA beswaar gemaak teen my betrokkenheid by die belydenis, maar die beswaar is afgewys. (Die konsepvorm van hierdie belydenis is deur my tydens 'n internasionale teologiese konferensie (IRTI) in Junie 1997 in Stellenbosch geformuleer.)

33 Brink (p. 251) verwys kritiekloos na die Skrywersgilde wat in 1975 tot stand gekom het en waar daar tydens byeenkomste gesellig verkeer, buitensporig gedrink en dikwels "flink hoereer" is en waar menige huwelik 'n knou gekry het. My vraag is waarom word soveel aandag aan politieke en sake-etiek gegee en so min aan huweliksetiek? Brink (2009a:14) vertel hoedat die vroueeksistensialis Simone de Beauvoir tevergeefs probeer het "om Camus in die bed te kry en hy die vermetelheid gehad het om te weier!" Dit laat die vraag ontstaan hoe die seksuele en huweliksetiek lyk wat die eksistensialisme voorstaan. Kom dit op volslae morele relativisme in die vorm van hedonisme neer? Sou dit vir Brink aanvaarbaar wees dat hy, terwyl hy met Karina getroud is, 'n nag saam met 'n ander vrou deurbring, of sy met 'n ander man? Indien nie, waarom nie? Brink erken dat sy Europese toer van 1964 saam met Ingrid Jonker 'n "kul"-reis was aangesien hy daardie tyd nog getroud was (kyk Metelerkamp \& Jonker, 2003:148). Op 1 Mei 1965 skryf Ingrid 'n (ongeposte) brief aan 'n vriend waarin sy meld dat sy "oneindig moeg word vir André se gespletenheid. Hoe sy vrou dit nog kan hóú na ORGIE!" (Metelerkamp \& Jonker, 2003:176). Francken (2011:103) verwys in hierdie verband na 'n opmerking van Ester: "Hij [Ester] is verontwaardigd over de oppervlakkigheid waarmee Brink schrijft over opeenvolgende liefdesrelaties ... Op geen enkel moment komt Brink tot het inzicht dat hij zich zeer schuldig heeft gemaakt ten opzichte van Ingrid Jonker." 
naamlik van Augustinus wat elke vorm van seksualiteit met 'n donker bril benader het - dit is egter 'n tema op sy eie (vgl. Van Wyk, 2002:327-348). Augustinus het goed geweet dat seksualiteit 'n wilde perd is om in te breek en teuelloos losgelaat, enige grensdraad sal platloop. Die moderne Calvinisme het egter 'n oper oog vir seksualiteit as 'n gawe van God wat beleef en geniet kan word.

Tweedens moet die sterk punte van die bestaande lewensbeskouing deeglik verreken word. Ek wonder of Brink ooit die beroemde Institusie (1559) van Calvyn onder oë gehad het. Om 'n lewenskeuse te maak, is dit immers noodsaaklik en wetenskaplik verantwoord om nie net op jou persepsie en individuele ervaring van 'n lewensbeskouing te reageer nie, maar om na die uiteensettings van die groot vertolkers van daardie lewensvisie te gaan kyk. Dis tog net billik dat 'n mens die primêre bronne (ad fontes) self gaan raadpleeg, of andersins 'n standaardwerk oor Calvyn of die Calvinisme bestudeer. ${ }^{34}$

Die Calvinisme word gewoonlik in terme van die vyf bekende solismes van die Reformasie van die sestiende eeu gedefinieer, naamlik aan God alleen die eer (soli Deo gloria), Christus alleen (solo Christo), genade alleen (sola gratia), geloof alleen (sola fide) en die Skrif alleen (sola Sriptura). Wie hierdie vyf solismes van nader ontleed, sal opmerk dat dit daarin oor 'n God van genade gaan wat in liefde na stukkende mense uitreik en aan hulle 'n hoopvolle toekoms bied. Dit is 'n boodskap van geloof, hoop en liefde; 'n boodskap van die aanbreek van die koninkryk van God (gekenmerk deur vrede, vreugde, vryheid en geregtigheid) wat aan 'n mens se lewe sin, diepte en uitsig gee. In sy boek het Brink net té haastig oor hierdie temas beweeg, of dit volkome geïgnoreer. Het hy ooit die Calvinisme na sy diepste intensie goed begryp? Dit val ook op dat Brink geen melding maak van die goeie dinge wat die Calvinisme wel onderneem het of wat uit hierdie lewensbeskouing voortgevloei het nie, byvoorbeeld die oprigting van skole, universiteite, aftree-oorde en onnoembaar veel welsynswerk (vgl. byvoorbeeld Schulze, 1985). Wat kan die eksistensialisme in hierdie verband toon wat enigsins hiermee vergelykbaar is?

Die sterk punte van die Calvinisme is dat dit fassinerend en hoopgewend is, dat dit rekening hou met transendensie, met God, met méér is as die sigbare werklikheid; dat dit die boodskap bring dat die

34 By Calvyn sou Brink nié net van protes kon verneem nie, maar (onder bepaalde voorwaardes) selfs van gewelddadige verset deur volksleiers teen ' $n$ boosaardige regering (vgl. Van Wyk, 1991:67-73). 
mens nie aan sy eie lot oorgelaat is nie - daardie mens wat hom hoe langer hoe meer in sy eie uitvindsels en tegnologie toespin, sonder hoop en sonder uitsig. Die sterk punt is verder dat die Calvinisme rekening hou met die eskatologie, met die toekoms, die Groot Toekoms, wat aan ons stukkende aardse bestaan sin gee. Dit gee dus ook sin aan die politiek, die ekonomie, die ekologie, die kuns en kultuur en die literatuur. Is die oorsprong van die demokratiese staatsvorm dan nie juis by die Calvinisme te vind nie?

Dit kan van iemand wat "op soek gaan" ten derde verwag word om hom nie net op die eerste beste lewensbeskouing vas te lê nie, maar om alle beskikbare modelle aan 'n grondige ondersoek te onderwerp. Waarom het Brink so oorhaastig en byna halsoorkop vir die eksistensialisme gekies? Waarom het hy Christus so vinnig vir Camus ingeruil? Indien hy dan 'n besondere voorkeur vir die eksistensialisme ontwikkel het, waarom het hy (veral as destydse Christen) nie ook ander eksistensialiste ondersoek en oorweeg nie soos byvoorbeeld Kierkegaard? By Kierkegaard sou hy die volgende kon lees:

Dít waaroor die Kommunisme so hoog opgee is vir die Christendom die mees vanselfsprekende saak, naamlik dat alle mense voor God wesenlik gelyk is, almal wesenlik gelyk! Maar die Christendom huiwer vir die monsteragtige [gedagte] wat God wil afskryf en die vrees vir mensemassa aanjaag, vir die meerderheid, die volk, die publiek. (Kierkegaard, 1971:172.)

Waarom nie ook talle ánder lewensbeskouings oorweeg nie: die rasionalisme van Descartes, die kritisisme van Kant, die idealisme van Hegel, die pessimisme van Schopenhauer, die positivisme van Comte, die nihilisme van Nietzsche, die pragmatisme van James, die ateïsme van Feuerbach, die materialisme van Marx ${ }^{35}$ of die relativisme van die postmodernisme? ${ }^{36}$ Dan het ek nog nie eers na die verskillende teologiese modelle verwys wat in die twintigste eeu ontstaan het nie soos die dialektiese teologie (Barth), die bevrydings-

35 Brink merk wel in hierdie verband op dat hoewel hy begrip het vir sommige Marxistiese beskouings oor geskiedenis en literatuur, hy nog altyd agterdogtig was oor die ideologie se utopiese bowetone en oor die vernietigende praktyke van die Stalinisme (2009:328).

36 Ek is deeglik bewus daarvan dat al hierdie -ismes nie noodwendig 'n (volledige) lewensbeskouing verteenwoordig nie, maar op epistemologiese vertrekpunte dui wat vir 'n lewensbeskouing wesensbepalend is. 
teologie (Gutiérrez), die swart teologie (Tutu), ${ }^{37}$ die feministiese, die Afrikateologie en die postmoderne teologie, ensovoorts. Miskien is dit te veel gevra om van iemand te verwag om op die hoogte te bly met die wêreldletterkunde én met al die filosofieë én met al die teologieë. Juis daarom moet 'n mens so deeglik oorweeg en so versigtig kies.

Waarom het Brink nie ook die groot Oosterse lewensbeskouings ontgin nie? Die Hindoeïsme, met Gandhi as ligtende voorbeeld?38 Of die Zen-Boeddhisme, waarby belangrike skrywers soos Breyten Breytenbach, Karel Schoeman, Eben Venter, asook die filosoof Johann Rossouw, aansluiting vind of waarvoor hulle belangstelling toon? Dus, waarom so haastig, onkrities, ongeweeg, voortvarend, byna naïef vir die eerste beste lewensbeskouing, wat van die Calvinisme verskil, naamlik die eksistensialisme (van Camus), kies? Waarom het Brink nêrens die vooronderstellings en die vertrekpunte van die eksistensialisme aan 'n kritiese ondersoek onderwerp nie? Brink het, myns insiens, nie daarin geslaag om sy "kubistiese denkmetode" breed genoeg aan te lê nie. Hierdie metode vra nie net wát ander mense dink nie, maar veral wáárom hulle so dink (p. 140).

Vierdens en vyfdens vra 'n nuwe keuse dat ook die sterk en swak punte van 'n nuwe lewensbeskouing oorweeg sal word. Die blywende waarde van die eksistensialisme is ongetwyfeld geleë in die verset teen die koue rasionalisme asook die idealisme (van Hegel), die verset teen absurditeit, objektiwiteit en onvryheid in die lewe. Dit vra aandag vir die mens as verantwoordelike individu wat in vryheid in elke konkrete situasie moet kies (vgl. Stumpf, 1988:474-510). By Camus speel twee begrippe 'n bepalende rol, naamlik absurditeit en verset. Die lewe is absurd en hierdie arbsurditeit kan net deur 'n daad van revolte oorwin word.

Tereg lê Brink in hierdie verband ook klem op morele waardes soos eerlikheid en integriteit (p. 150), terwyl hy ook (soos die Calvinisme) liefde as sentrale gegewe in die lewe beskou (p. 335), hoewel die heel grootste - in extremis - vir hom vryheid is (p. 301, 308). Die

37 Vergelyk Brink se veelseggende opmerking: "Ek is nie 'n Christen nie. Maar een van die bloedmin Christene wat ek ooit in my lewe ontmoet het wat my laat voel het dat daar dalk - dálk - iets daarvoor te sê mag wees, is Desmond Tutu" - en dan voeg hy die name by van Beyers Naudé en Rob Antonissen (p. 455). Vergelyk in hierdie verband die boeiende biografie van Allen (2006) oor Tutu.

38 Vergelyk Yancey (2005:132-157) en ook Brink (p. 388) oor Gandhi, wat nie net téén dinge was nie maar ook daarvóór . 
groot vraag is egter watter inhoude aan die begrippe liefde en vryheid gegee word. Impliseer dit byvoorbeeld politieke regverdigheid en ekonomiese billikheid, maar sluit seksuele losbandigheid in? Waar kom die norme vandaan wat hier as maatstawwe kan dien? Indien dit in die mens self geleë is, en Brink soek inderdaad die vertrekpunt vir ' $n$ bevredigende ideologie in homself (p. 329), is subjektiewe willekeur en kontradiksie dan nie 'n noodwendige en logiese uitvloeisel nie?

Sowel die Calvinisme as die eksistensialisme gee aan die vraagstuk van geweld besondere aandag. Dit is duidelik dat Brink teen nagenoeg alle vorms van geweld gekant is. Trouens, die eerste hoofstuk maak dit reeds duidelik. 39 Hy spreek hom deurlopend sterk uit teen die institusionele (of strukturele) geweld wat die apartheidsregering onderlê het (soos reeds aangetoon is). Hy kritiseer ook die fisiese geweld wat apartheid veroorsaak het, asook dít wat tans deur die ANC-regering ten toon gestel word (p. 440-474). "In die veranderde omstandighede in Suid-Afrika is die ANC besig om presies dieselfde rol te speel as die Nasionale regime onder apartheid." (p. 469.) "Die huidige regering het 'n skande geword vir die party se geskiedenis." (p. 464.)

Terwyl Brink in 2004 nog "versigtig optimisties" oor die toekoms van Suid-Afrika was (Wroe, 2004:45), merk hy in 2008 op dat die kortsigtigheid, gulsigheid en arrogansie van ons nuwe heersers sy geloof laat verkrummel het in die spesifieke soort toekoms waarin hy vas geglo het en waarvoor hy bereid was om sy eie prys te betaal (Brink, 2008:6). Kort nadat sy susterskind deur rowers doodgeskiet is, verklaar hy: "Dit is onaanvaarbaar dat Suid-Afrika oorgelaat is aan die genade van barbare", en "dit blyk dat die regering nie meer kan regeer nie" (Fourie, 2008:1). Hy verklaar uitdruklik dat hy so lank as wat dit moontlik is nie sal stilbly om teen die morele bankrotskap van die ANC te getuig nie (p. 473, 474).

Hy spreek hom selfs uit teen die geweld teen diere, en teen jag (p. 33), en vertel hieromtrent 'n (redelik ongeloofwaardige) verhaal. Die verhaal gaan daaroor dat hy by geleentheid veertien voëltjies in 'n ogiesdraadhok (met tregtervormige ingang) gevang het. Hy het die een voëltjie met groot moeite nekomgedraai en wou die ander

39 Vergelyk die volgende vraag: "Is dit waarom daar in 'n daad of sisteem van foltering altyd ' $n$ ideaal van suiwerheid, van absoluutheid verskuil is, van iets groter as onsself: 'n uiteindelike geregtigheid, Christelikheid, Ariesheid, Witheid?" (p. 365). 
dertien loslaat. Toe hy nie daarin kon slaag nie, was al oplossing om by die bure 'n windbuks te leen en die dertien dood te skiet. "Daar was geen manier waarop hulle uit die hok kon kom nie" (p. 32). Indien hy hulle dan so graag lewendig wou loslaat, waarom het hy nie 'n tang geneem (of by die bure een geleen) en die hok eenvoudig oopgeknip en die voëls laat wegvlieg nie? Die hok kon tog sekerlik maklik agterna herstel word.

'n Groter probleem is die feit dat Brink uiters reduksionisties met die term geweld omgaan, naamlik as institusionele en fisiese geweld. Maar wat van psigiese geweld? $\mathbf{4 0}$ Is die onsimpatieke en onwelwillende manier waarop hy na mense verwys en hulle beskryf nie 'n vorm van verbale en psigiese geweld en daarom moreel aanvegbaar nie? Om enkele voorbeelde te noem: "arme, arrogante, swakkeling" (Ingrid se pa) (p. 103), die "gatkruiper" en "aartskonkelaar" (Piet Cillié) (p. 234, 343), "tweegatjakkals" (W.E.G. Louw) (p. 234), "literêre nonentiteit" (Abel J. Coetzee) (p. 235), "hanswors" (Marthinus van Schalkwyk) (p. 243), "nare klein mannetjie" (Lammie Snyman) (p. 251), "nonentiteit en hanswors" (Humphrey du Randt) (p. 258, 259). 41 Daar word twee keer daarna verwys dat P.G. du Plessis "nooit iets sou doen om die establishment aantstoot te gee nie" (p. 257, 343). Marike de Klerk word beskryf as 'n ontoeganklike mens wat in 1994 "nog steeds versteen was in die denkwyse van apartheid" (p. 448).42 Hang dit saam met wat Kannemeyer ook ten opsigte van Brink se ander romans opmerk: die "oordaad" (Kannemeyer, 2005:334), die "opstapeling" van talle vorms van geweld (Kannemeyer, 2005:338)? Dalk hang dit saam met wat Lindenberg (1998:310) sê: "Veral die hebbelikheid tot oppervlakkige vlotheid en sentimentaliteit bly knaag aan die potensiële meriete van sy skeppingswerking." 43 Daar is by Brink 'n deurlopende tendens van intensiteit en ekstremiteit.

40 Brink verwys wel na psigiese geweld in verband met politieke etiek (p. 388, 415), maar hy hanteer nie die begrip wanneer dit by huweliksetiek kom nie.

41 Du Randt het baie krities in Rapport (2009:iv) hierop gereageer.

42 In haar outobiografiese vertellings aan Maartens (1998:166-173) vertel Marike hoedat sy geleidelik van apartheid weggegroei en tot die besef gekom het dat "my volk het self onderdrukkers geword sonder dat hulle bedoel het om dit te word" (Maartens, 1998:167).

43 Vergelyk ook die debat oor die boek van R.W. Johnson, South Africa's brave new world, wat deur die bekwame historikus Hermann Giliomee as "die belangrikste ontleding van ons land sedert 1994" getipeer is, maar deur Brink as "oppervlakkige skinderstories" afgemaak is. Vir 'n kort weergawe van die debat, 
Meer problematies in hierdie verband is die wyse waarop Brink die vier vroue met wie hy getroud was (hy is tans met die vyfde, Karina Szczurek, getroud), ter sprake bring. Hulle was volgens Wroe (2004:44): Estelle Naudé (ma van Anton), Salomi Louw (ma van Gustav), Alta Miller (ma van Danie en Sonja) en Marésa de Beer. Van die vyf word slegs vier in die biografie genoem (Marésa ontbreek), terwyl net van Karina foto's verskyn. Van hierdie vyf vroue is slegs Karina 'n sleutelvrou, want "die sleutelvroue in my lewe is regtig net Ingrid, Hermione en Karina" (Meiring, 2009:iv). Slegs een van die vrouens met wie hy getroud was (Karina), word as "sleutelvrou" getipeer. Selfs die "lieflike Lise" (p. 90-92, 271-272) haal nie hierdie lysie nie. Hiervolgens was nie een van die vroue by wie Brink kinders verwek het "sleutelvroue" in sy lewe nie. Is dit nie verbale en psigiese geweld in 'n baie erge vorm nie? Is dit verteenwoordigend van die morele waardes en die seksuele etiek wat die eksistensialisme voorstaan?

Om saam te vat: dit is waar dat 'n keuse vir 'n bepaalde lewensbeskouing nie noodwendig klinies intellektueel gemaak word nie. Dieselfde geld ten opsigte van 'n keuse vir die eksistensialisme waar die benadering juis is dat "eksistensie aan essensie voorafgaan", met die gevolg dat die eksistensiële beslissing ook die teoretiese analise van lewensbeskouings voorafgaan. Uiteindelik is die keuse vir 'n bepaalde lewensbeskouing 'n geloofskeuse waarby aanvaar word dat daardie lewensbeskouing die sinvolste antwoorde op die diepste lewensvrae bied. Dit alles toegegee, ontneem die keusemaker egter nie die verantwoordelikheid om sy keuse minstens by nabaat deeglik te verantwoord nie.44

\section{Konklusie}

Die sondes van die Christendom, die Calvinisme asook die SuidAfrikaanse Calvinisme wat Brink breedvoerig uiteengesit het, is natuurlik waar. Trouens, die lysie kan nog baie langer gemaak word. Die fout wat die Afrikaanse kerke met apartheid begaan het, is nie 'n klein "glipsie" nie, maar 'n ernorme dwaling wat alleen deur skuldbelydenis en vergoeding (vir sover moontlik) herstel kan word.

vergelyk. Louw (2009:iv). Vir die siening van Giliomee oor Brink en die SuidAfrikaanse politiek, vergelyk Giliomee (2003:554, 584, 594).

44 Die aansoek vir en die aanvaarding van die Jan Rabie/Marjorie Wallace-beurs van R350 000 het die beeld van Brink baie skade berokken (vgl. slegs die reaksie van Botha, 2010). 
Soos Camus ken die Calvinisme ook die gedagte van protes. As Protestantse beweging is dit 'n beweging van protes teen elke vorm van onwaaragtigheid, leuenagtigheid, boosheid en onregverdigheid in kerk en samelewing. Wie nie protesteer nie, is nie bekeer nie, sou 'n mens met reg kon sê. Die ideaal van die Calvinisme is om na alles te streef wat reg, rein, mooi en deugdelik is. Dat dit telkens faal om hierdie hoë ideale waar te maak, is 'n oorsaak van diepe beskaming, maar nie 'n rede om nie telkens weer te probeer nie.

Die eksistensialisme slaag, myns insiens, nie daarin om die diepste lewensvrae bevredigend te beantwoord nie, omdat dit sy vertrekpunt in die mens self neem en van die absurditeit van die lewe uitgaan.45 Hierteenoor sien die Christelike geloof die sin van die lewe in die koms van die koninkryk van God en die mens se betrokkenheid daarby en diens daaraan. Die sin van die geskiedenis hou verband met die koms van Jesus Christus (vgl. Berkhof, 1959; Rossouw, 1981) as God se ja vir die mens, die aarde en die totale skepping. Die mens is nie 'n tonnelgrawer sonder lig en sonder hoop nie, maar hy kan in 'n stukkende wêreld diensbaar en hoopvol lewe - vol verwagting op 'n Groot Toekoms.

\section{Geraadpleegde bronne}

ALLEN, J. 2006. Rabble-rouser for peace: the authorized biography of Desmond Tutu. Houghton: Random House.

BERKHOF, H. 1959. Christus de zin der geschiedenis. Callenbach: Nijkerk.

BOTHA, M.C. 2010. Hoe durf jy vat wat jou nie toekom nie? Rapport/Weekliks: 3, 31 Jan.

BRINK, A.P. 1957. Christelik-nasionale onderwys in Suid-Afrika. Die Besembos, $31: 116-119$

BRINK, A.P. 2005. Bidsprinkaan: 'n ware storie. Kaapstad: Human \& Rousseau. BRINK, A.P. 2008. Lyfskryf: die rotte. Beeld/By: 6-7, 12 Jul.

BRINK, A.P. 2009a. 'n Vurk in die pad: 'n memoir. Kaapstad: Human \& Rousseau.

BRINK, A.P. 2009b. Op Camus se spoor. Beeld/By: 14-15, 5 Sept.

BURGER, W. 2010. Skrywersprofiel: want Brink kán vertel. Rapport/Boeke: 3, 7 Feb.

DE KLERK, F.W. 1998. Die laaste trek - 'n nuwe begin: die outobiografie. Kaapstad: Human \& Rousseau.

DE KLERK, W.J., DUVENAGE, B. \& VAN WYK, J.H. 1972. Roeping en werklikheid. Potchefstroom: Potchefstroom Herald.

DE VILLIERS, I. 2009. Strooidak en toring: van mense en my tyd. Kaapstad: Umuzi.

45 Volgens Brink (p. 365) is lyding ook absurd - volkome "nutteloos". 
DU RANDT, H. 2009. André P. Brink: hoe kaler jonker, hoe groter pronker. Rapport/Weekliks: iv, 1 Mar.

FOURIE, H. 2008. Oorgelaat aan barbare: André Brink spoeg vuur. Beeld: 1, 16 Mei.

FRANCKEN, E. 2011. Een groot mirakel: de Afrikaanse literatuur in Nederland in 2010. Tydskrif vir Geesteswetenskappe, 51(1):101-104.

GILIOMEE, H. 2003. The Afrikaners: biography of a people. Kaapstad: Tafelberg.

HUGO, D. 2005. Brink se "beste boek": Van kakkerlak tot hottentotsgot. Insig: 47, Aug.

JONKER, W. 1998. Selfs die kerk kan verander. Kaapstad: Tafelberg.

KANNEMEYER, J.C. 2005. Die Afrikaanse literatuur 1652-2004. Kaapstad: Human \& Rousseau.

KIERKEGRAAD. 1971. Dagboeknotities: een keuze. Vert. door W.E. Scholtens. Baarn: Ten Have.

KLEINBOER. 2003. Kontrei: roman. Dainfern: Praag.

KUITERT, H.M. 1962. De mensvormigheid Gods: een dogmatischhermeneutisch studie over de anthropomorfismen van de Heilige Schrift. Kampen: Kok.

LABUSCHAGNE, M. 2007. Afrikaner-vryheid en "die dood van God". Beeld: 3, 15 Sept.

LINDENBERG, A. 1998. André P. Brink. (In Van Coller, H.P., red. Perspektief en profiel: 'n Afrikaanse literatuurgeskiedenis. DI. 1. Pretoria: Van Schaik. p. 294-315.)

LOOTS, S. 2004. Brink-roman geen "kiss \& tell". Rapport/Perspektief: iv, 31 Okt.

LOUW, C. 2001. Boetman en die swanesang van die verligtes. Kaapstad: Human \& Rousseau.

LOUW, C. 2009. André P. Brink se kleingeestigheid verstommend. Rapport/Weekliks: iv, 26 Apr.

MAARTENS, M. 1998. Marike: 'n reis deur somer en winter - oorvertel deur Maretha Maartens. Vaderbijlpark: Carpe Diem.

MAKER, A. 2001. Something new out of Africa: Christian en African spirituality meet to give hope for world humanity. The Princeton seminary bulletin, 22(2):185-202.

MEIRING, M.R. 2009. Brink swiep wyd en soms genadeloos. Rapport/Weekliks: iv, 22 Feb.

METELERKAMP, P. \& JONKER, A. 2003. Ingrid Jonker: beeld van 'n digterslewe. Hermanus: Hemel \& See Vermont.

NAUDÉ, B. 1995. My land van hoop: die lewe van Beyers Naudé. Kaapstad: Human \& Rousseau.

OLIVIER, F. 2009. Brink vat himself in kompartemente vas. Beeld: 11, 2 Mar.

RETIEF, H. 2005. Geen droë wit seisoen op 70 nie! Rapport/Perspektief: 3, 19 Jun.

ROSSOUW, H.W. 1981. Die sin van die lewe. Kaapstad: Tafelberg.

ROTHUIZEN, G. Th. 1962. Primus usus legis: studie over het burgerlijk gebruik van de wet. Kampen: Kok.

SCHULZE, L. 1985. Calvin and "social ethics": his views on property, interest and usury. Pretoria: Kital.

SCHUTTE, G. 2005. De Vrije Universiteit en Zuid-Afrika 1880-2005. Deel 1 \& 2. Meinema: Zoetermeer. 
SCOTT, W. 1998. Prof. Tjaart van der Walt (1977-1988). (In Reinecke, C.J., red. Verkennings in oorgang: gedagtes by die 125-jarige bestaansjaar van die PU vir CHO - 1994. Koers, Supplement 1:73-82.)

SNYMAN. W.J. 1977. Nuwe en ou dinge: "Uit die skat van die koninkryk". Potchefstroom: Pro Rege.

STANDER, C. 2009. Die Brink kant bly bo. Rooi Rose: 28-29, Mar.

STEYN, J.C. 2008. Sonkyker: Afrikaner in die verkeerde eeu. Kaapstad: Tafelberg.

STOKER, H.G. 1961. Beginsels en metodes in die wetenskap. Potchefstroom: Pro Rege.

STOKER, H.G. 1967. Oorsprong en rigting. Band 1. Kaapstad: Tafelberg.

STOKER, H.G. 1970. Oorsprong en rigting. Band 2. Kaapstad: Tafelberg.

STUMPF, S.E. 1988. Socrates to Sartre: a history of Philosophy. New York: McGraw-Hill.

VAN DER SCHYFF, P. 2003. Sages en legendes en ander lekker stories oor die PUK. Vol. 1. Potchefstroom: PU vir $\mathrm{CHO}$.

VAN DER VYVER, M. 2008. In gesprek met Marida Fitzpatrick. Beeld: 11, 4 Okt.

VAN DER WALT, T. 1962. Die koninkryk van God - naby! Eksegetiese verkennings van die toekomsperspektief van Jesus Christus volgens die getuienis van die Sinoptiese Evangelies. Kampen: Kok.

VAN DER WALT, T. 2006. Die Messias het gekom! 'n Gids in die Evangelies vir toegwyde Bybel-studente. Potchefstroom: Potchefstroomse Teologiese Publikasies.

VAN DER WALT, T. 2009. Between Pentecost and consummation: a guide to the second half of the New Testament for dedicated students. Potchefstroom: Potchefstroom Theological Publications.

VAN EEDEN, E.S., red. 2005. "In U lig": die PU vir CHO van selfstandigwording tot samesmelting 1951-2004. Potchefstroom: Noordwes-Universiteit.

VAN WYK, J.H. 1991. Moraliteit en verantwoordelikheid: opstelle oor politieke etiek. Potchefstroom: $\mathrm{PU}$ vir $\mathrm{CHO}$.

VAN WYK, J.H. 1993. Homo Dei: 'n prinsipiële besinning oor enkele mensbeskouings, waaronder dié van Calvyn. In die Skriflig, Supplementum 1.

VAN WYK, J.H. 2002. Venialis culpa? Augustinus oor huwelik en seksualiteit. In die Skriflig, 36(3):327-348.

VAN ZYL SLABBERT, F. 2006. Duskant die geskiedenis: 'n persoonlike terugblik op die politieke oorgang in Suid-Afrika. Kaapstad: Tafelberg.

WROE, N. 2004. Die lewe en liefdes van André P. Brink. Insig: 42-45, Nov.

YANCEY, P. 2005. Spirituele oorlewing: hoe my geloof die kerk oorleef het. Vereeniging: Christelike Uitgewersmaatskappy.

\section{Kernbegrippe:}

Brink, André $P$.

Calvinisme

Calvyn

Camus

eksistensialisme 


\section{Key concepts:}

Brink, André $P$.

Calvin

Calvinism

Camus

existentialism 